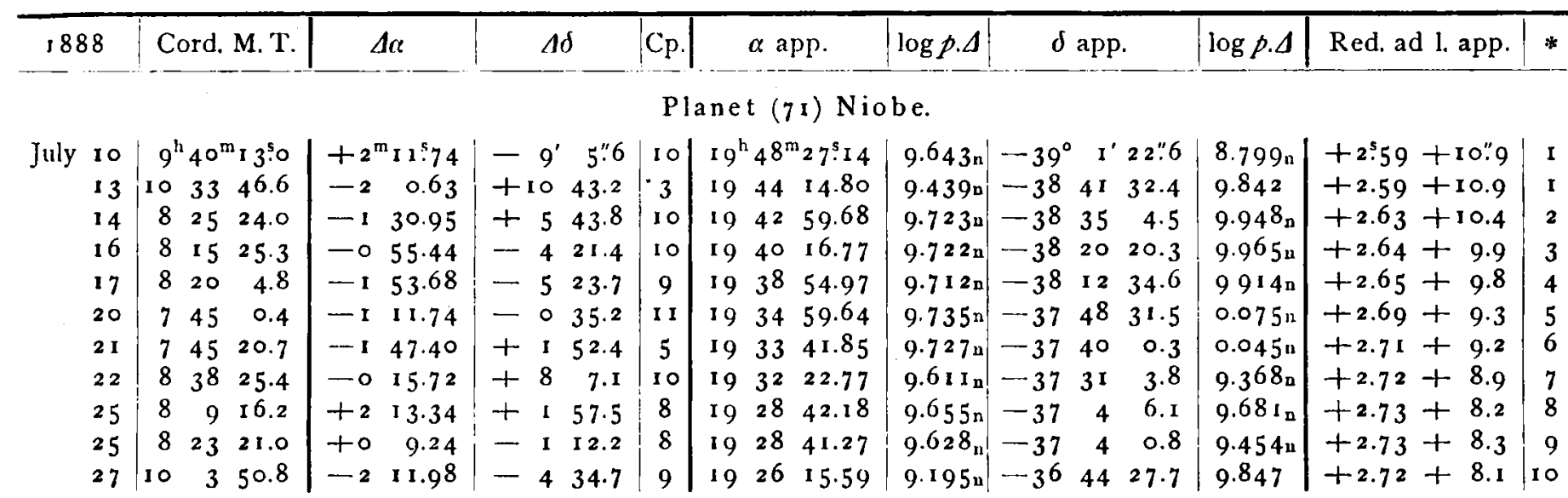

July 13. Through clouds, poor. - July I 4. Dense haze. - July 25 . Clouds and wind. - July 27. Very faint.

Mean Places of the Comparison Stars for 1888.0.

\begin{tabular}{|c|c|c|c|c|c|c|}
\hline * & Mag & $\alpha 18$ & 88.0 & & 1888.0 & Authority \\
\hline \multicolumn{7}{|c|}{ For Encke's Comet I 888 II. } \\
\hline I & $93 / 4$ & $11^{11} 25$ & 19.50 & $\mid-10$ & $50^{\prime} 58.9$ & Cord. Mer. \\
\hline 2 & 10 & $1 \mathrm{I} 3 \mathrm{I}$ & 33.62 & -12 & $\begin{array}{lll}6 & 22.3\end{array}$ & Cp. with $W_{1} \geq 1.439$ \\
\hline 3 & $91 / 4$ & I I 43 & 3.17 & -13 & 1216.0 & Cord. Mer. $\left(W_{1} 716\right)$ \\
\hline 4 & 8 & I I 52 & 50.02 & -14 & $29 \quad 31.8$ & Cord. Mer. $\left(W_{1} 788\right)$ \\
\hline 5 & $81 / 4$ & I I 53 & 41.79 & -15 & $25 \quad 40.5$ & Cord. Mer. $\left(W_{1} 890\right)$ \\
\hline 6 & $83 / 4$ & 12 & 4.92 & -17 & $46 \quad 44.0$ & Cord. $\mathrm{Mer} .\left(\mathrm{AOe}_{2}\right)$ \\
\hline 7 & $9^{1 / 4}$ & 12 & $53.8 \mathrm{I}$ & -19 & $31 \quad 17.7$ & Cord. Mer. $\left(\mathrm{AOe}_{2}\right)$ \\
\hline 8 & $63 \%$ & I 445 & 53.10 & -30 & $6 \quad 52.0$ & Cord.GC. 20135 \\
\hline 9 & 7 & 1452 & 44.01 & -30 & 1542.4 & Cord.GC. 20313 \\
\hline 10 & $6^{1 / 2}$ & 1459 & $45 \cdot 4^{6}$ & -30 & 2857.1 & Cord. GC. 20484 \\
\hline \multicolumn{7}{|c|}{ For (26) Proserpina. } \\
\hline $\mathbf{I}$ & $81 / 4$ & 1733 & 51.23 & -27 & $20 \quad 0.5$ & Cord.GC. 23949 \\
\hline 2 & $83 / 4$ & 1730 & 4.09 & -27 & I 36.3 & Cord.Mer. (ZC.1981) \\
\hline 3 & $9^{1 / 4}$ & 1723 & 33.63 & -27 & $6 \quad 49.9$ & Cord.Mer. (ZC.1 542) \\
\hline
\end{tabular}

Cordoba 1889 June 30.

\begin{tabular}{|c|c|c|c|c|}
\hline$\%$ & Mag. & $\alpha 1888.0$ & $\delta 1888.0$ & Authority \\
\hline & 9 & $17^{\mathrm{h}} 16^{\mathrm{m}} 4^{8 \mathrm{~s}} .68$ & $-27^{\circ}$ I $9^{\prime}$ I $1 . " 0$ & Cord. Mer. (ZC. 1085$)$ \\
\hline & $7 \frac{1}{2}$ & $\begin{array}{lll}17 & 14 & 5.08\end{array}$ & $\begin{array}{lll}-27 & 18 & 14.2\end{array}$ & Cord.GC. 23475 \\
\hline 6 & 8 & I 7 I 354.59 & $\begin{array}{lll}-27 & \text { I } 3 & 40.8\end{array}$ & Cord. Mer. (ZC.897) \\
\hline
\end{tabular}

For (7 1) Niobe.

\begin{tabular}{|c|c|c|c|c|c|c|c|c|}
\hline $\mathbf{I}$ & 9 & 19 & & I $2.8 \mathrm{I}$ & $-3^{8}$ & 52 & 27.8 & Cord.Mer. (ZC.1 897) \\
\hline 2 & $83 / 4$ & I 9 & 44 & 28.00 & $-3^{8}$ & $4 \mathrm{I}$ & 8.5 & Cord.Mer. \\
\hline 3 & $81 / 2$ & 19 & 4 I & 9.57 & $-3^{8}$ & I 6 & 8.8 & Cord. Mer. (ZC. I 7 I I) \\
\hline 4 & $73 / 4$ & 19 & 40 & 45.99 & $-3^{8}$ & 7 & 20.8 & Cord.GC. 27093 \\
\hline 5 & 6 & 19 & $3^{6}$ & 8.68 & -37 & 48 & 5.6 & Cord. GC. 26987 \\
\hline 6 & $7^{1 / 4}$ & 19 & 35 & 26.54 & -37 & 42 & I.9 & Cord. GC. 2697 I \\
\hline 7 & 8 & 19 & 32 & 35.77 & -37 & 39 & 19.8 & Cord. GC. 26896 \\
\hline & 9 & 19 & 26 & 26.11 & -37 & 6 & I 1.8 & Cord. GC. 26775 \\
\hline 9 & $71 / 2$ & 19 & 28 & $29.3^{\circ}$ & -37 & 2 & 56.9 & Cord.GC. 268 I 3 \\
\hline & $9^{1 / 2}$ & 19 & 28 & 28.45 & $-3^{6}$ & 40 & 1.1 & Cord. Mer. (ZC. I I 7 7) \\
\hline
\end{tabular}

Fohn M. Thome.

\title{
Observations of Faye's Comet 1888 IV
}

\section{by E. E. Barnard, Astronomer of the Lick Observatory.}

The following observations of Faye's Comet have been made with the filar micrometer of the 12 inch. equatorial. It was very difficult to observe and has required the utmost care and patience throughout.

It was easily found the same night that the dispatch announcing its discovery at Nice was received, and, I think, it could have been seen here probably from one to two months earlier, had its place been known.

Absence on our eclipse expedition prevented obser. vations during nost of December and January, and work on the photographic results of that expedition has delayed the preparation of the observations for printing until now.

Several attempts to refind the comet after the February moon proved futile, as no ephemeris was at hand, and later, when an ephemeris was received, our bad weather had set in and it was not seen again.

When first looked for on Feb. 4 the comet could not be found at $\mathrm{I}^{\mathrm{h}}$, but upon very close examination a $9^{\text {m }}$ star - used later for comparison - was seen to be apparently nebulous, a faint glow almost symmetrically surrounding it. At ${ }_{11}{ }^{\mathrm{h}} 15^{\mathrm{m}} 54^{\mathrm{s}} \mathrm{M}$ : Ham. m. t. by careful estimation the center of this nebulosity was certainly not over $2^{\prime \prime}$ or 3 " following the star, which will give the place with accuracy. Returning to this place later at night the comet was seen to have left the star and was some little distance n. p. where it was observed with the micrometer.

In the observation of Aug. 10 the comet was carefully 
watched, until it and the comparison star were exactly on the same parallel - as bisected by the wire - this was then corrected for motion to the epoch of $\Delta \alpha$.

The smallness of the comet has been quite striking. It was at no time over $30^{\prime \prime}$ in diameter - a little brighter in the middle - its light being more like that of one of the small indefinite nebulae than that of a comet. It was brightest and easiest to observe about the first part of December.

The comparison star of Feb. 4 was inadvertently compared with the star DM. +2.1734 instead of with $W_{1} 7^{\text {h }} \cdot 9^{8} 3$, as was at first supposed.

In A. N. 2859 , in the Nice Observations, the seconds of right ascension for Aug. I 4 should be 59 instead of 49, as will be seen by applying the $\Delta \alpha$ to the star's place.*)

The value of a revolution of the micrometer screw adopted and used in these observations is I 4.057 10.004 . The observed $\Delta \alpha$ have been recorded by seye and ear. In our micrometer there are but two spider threads, and in observing, a set of $\Delta \delta$ was made and the micrometer revolved $90^{\circ}$ and a set of $\Delta \alpha$ taken over the two wires, the micrometer revolved back and another set of $\Delta \delta$ made. With care, the mean of the times for the two sets of $\Delta \delta$ almost always agreed with the mean of the times for $\Delta \alpha$ to one minute. These were then corrected by the known motion to the same epoch.

The observations have been corrected for differential refraction.

Filar Micrometer Observations of Faye's Comet 1888 IV

made with the ra inch. Equatorial of the Lick Observatory by E. E. Barnard.

\begin{tabular}{|c|c|c|c|c|c|c|c|c|c|c|c|c|c|c|c|c|c|c|c|c|c|}
\hline \multirow{2}{*}{\multicolumn{2}{|c|}{$\frac{\text { I 888-89 }}{\text { Aug. } 10}$}} & \multicolumn{3}{|c|}{ MtH. M. T. } & & \multicolumn{3}{|c|}{$\Delta \delta$} & \multirow{2}{*}{$\frac{\text { Cp. }}{8}$} & \multicolumn{3}{|c|}{$\alpha$ app. } & \multirow{2}{*}{$\frac{\log p \cdot \Delta}{9.672_{\mathrm{n}}}$} & \multicolumn{3}{|c|}{$\delta$ app. } & \multirow{2}{*}{$\frac{\log p .4}{0.622}$} & \multicolumn{2}{|c|}{ Red. ad 1. app. } & \multirow{2}{*}{ * } \\
\hline & & $15^{\mathrm{h}}$ & $\mathbf{I}^{\mathbf{m}}$ & $48^{s}$ & $-0^{m}$ & 03 & - & $0^{\circ}$ & o.8 & & $5^{h}$ & & 97 & & +19 & & & & +0.52 & $-2 " 6$ & \\
\hline & 11 & 15 & 18 & 44 & $-\mathbf{I}$ & & + & $\circ$ & 9.9 & 9.5 & 5 & & & & +19 & 55 & & 0.604 & .52 & -2.6 & 2 \\
\hline & 12 & $\mathbf{I} \mathbf{5}$ & 15 & 59 & +o & & - & 2 & 23.0 & 0.12 & & & & & +19 & 53 & & .609 & & & 2 \\
\hline & 13 & 15 & & $3^{2}$ & -1 & & - & ० & 5.8 & 7.1 & & - & & $9.65 I_{n}$ & & - & & 0.609 & 55 & -2.6 & 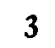 \\
\hline & 14 & 14 & 59 & $3^{8}$ & to & & + & 5 & 26.6 & $7 \cdot 5$ & 5 & & & & +19 & 47 & & .619 & 57 & & 4 \\
\hline & 15 & $\mathbf{I}$ & 15 & 29 & $t-3$ & & + & 2 & $24 \cdot 3$ & & 5 & & 3 & & +19 & 44 & & 0.600 & 61 & -2.5 & \\
\hline & 16 & 15 & 44 & $5 \mathrm{I}$ & to & & + & & 2.4 & 10.3 & & & & $4 n$ & & - & & 0.563 & +0.62 & -2.6 & \\
\hline & 17 & 15 & 30 & 27 & -0 & & - & 3 & $3^{6.6}$ & 1.4 & & & & & & - & & $0.5^{8}$ & 64 & -2.5 & \\
\hline & 18 & 15 & $3^{8}$ & 29 & +0 & & + & 0 & $27 \cdot 3$ & 0.4 & 5 & 25 & 37.61 & & +19 & 33 & 22.6 & 0.586 & 66 & -2.5 & 7 \\
\hline & 7 & 16 & 4 & 0 & -0 & & + & 3 & 54 & 12.5 & & & & & & - & & 89 & 23 & -2.8 & \\
\hline & 8 & I 6 & 33 & 34 & -0 & & + & 5 & & $4 \cdot 3$ & 7 & 22 & & $9.283^{n}$ & +12 & 27 & $5^{6.5}$ & $0.5^{82}$ & +1.41 & -3.0 & 9 \\
\hline & 15 & I 6 & 46 & 50 & to & & + & 6 & 42.4 & .5 & 7 & & & $9.12 \mathrm{In}$ & +11 & 8 & 10.1 & & 57 & -4.2 & 10 \\
\hline v. & 4 & I 6 & 4 & 42 & +o & & - & 4 & 9.9 & & 7 & 58 & & $9.045 n$ & +7 & 10 & 9.8 & & 7 & -4.8 & $I$ \\
\hline & 10 & 15 & 2 & $3 \mathrm{I}$ & $-I$ & & - & 5 & 35 & 12.6 & 8 & 4 & & $9.276_{\mathrm{n}}$ & +6 & 2 & 50.8 & 0.666 & 4 & -5.5 & 2 \\
\hline & 28 & 12 ! & 59 & 28 & -2 & & - & 0 & 34 & 0.7 & 8 & 12 & & & +3 & $\circ$ & 24.1 & 0.705 & 7 & -7.4 & I 3 \\
\hline & I & 12 & 46 & I I & -0 & & - & 2 & 36 & 12.6 & 8 & 12 & & & +2 & 34 & $27 \cdot 4$ & .708 & & -7.9 & 14 \\
\hline & 2 & I 2 & 3 I & 2 I & -0 & & - & 1 & 35 & 6.5 & 8 & 12 & 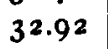 & & +2 & 26 & 53.5 & 0.712 & 68 & -8.1 & 15 \\
\hline & 5 & 12 & 22 & 30 & -1 & & + & 6 & & 8.6 & 8 & & 2 & & +2 & 3 & 7.9 & 0.714 & 8 & -8.5 & 16 \\
\hline & 6 & I 2 & 9 & 29 & $-\mathbf{I}$ & & - & 0 & & 8.3 & 8 & 12 & 14. & & +1 & $5^{6}$ & 0.4 & 3 & 80 & - & 16 \\
\hline & $2 \mathrm{I}$ & 9 & 51 & 3 & to & & + & 6 & 15.0 & 6.6 & 7 & 41 & & $9.318 n$ & +1 & 17 & $39 \cdot 3$ & $0.7 \times 6$ & +0 & -5.3 & 17 \\
\hline & 22 & Io & 18 & .7 & +o & & + & 2 & $5^{8.3}$ & I 6.6 & 7 & $4 I$ & & $9.149 n$ & +1 & 23 & 0.0 & 0.713 & & - & 18 \\
\hline & 23 & 9 & 42 & 54 & -0 & 26.96 & + & 8 & I. 6 & 14.8 & 7 & 40 & & & +1 & 28 & 3.0 & 0.714 & 58 & -5.6 & 18 \\
\hline & 25 & 10 & 20 & 46 & $\longrightarrow 1$ & & - & 0 & 48.4 & 10.7 & 7 & 38 & & & +1 & 39 & 21.1 & 0.7 II & 59 & & 19 \\
\hline & 26 & I I & 2 & 44 & -0 & & + & 0 : & 39.7 & 12 & 7 & 38 & & 8.2 & +1 & 45 & 25.4 & 0.710 & 59 & & 20 \\
\hline & 27 & 12 & 39. & 37 & +0 & & - & 0 & 9.0 & 12.6 & 7 & & & 9.262 & +1 & 51 & 59.7 & 0.710 & 59 & $-6 . \mathrm{r}$ & 21 \\
\hline & 2 & 10 & 53 & 28 & -0 & & 一 & 2 & 30.4 & 12.6 & 7 & 33 & & & +2 & 29 & 41.1 & 0.702 & & 5.6 & 22 \\
\hline & 3 & 10 & 9 & 51 & -0 & & + & $4^{\circ}$ & 7.2 & I 2.9 & 7 & 33 & 28.29 & $8.85^{1} n$ & +2 & $3^{6}$ & 18.6 & 0.700 & +0.60 & -6.7 & 22 \\
\hline & 4 & 14 & 36 & 18 & -0 & & + & $\mathbf{I}$ & I 1.6 & 10.5 & & - & & 9.616 & & - & & 0.713 & +0.59 & -6.7 & 23 \\
\hline & 5 & 12 & 22 & 40 & -0 & & + & 0 & 35.4 & 10.7 & & - & & & & - & & & & -6.8 & 24 \\
\hline & 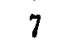 & 13 & 53 & $3^{8}$ & $-I$ & & - & 0 & $47 \cdot 5$ & 6.4 & 7 & 31 & 35 & & +3 & 4 & $\mathrm{~J}=\mathrm{A}$ & 0.708 & +0.57 & -7.0 & 25 \\
\hline
\end{tabular}

The observation of the $14^{\text {th }}$ of August made with a ring micrometer.

*) Vergl. die Berichtigung Bd. 120 S. 271. Kls. 


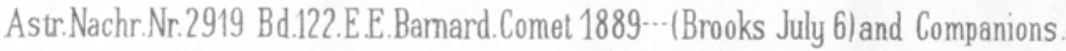
36 inch. Equatorial of the Lick Observatory,1889 August 4.

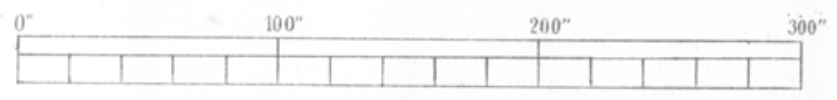




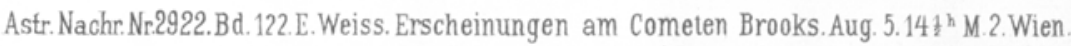


Mean Places of the Comparison stars for the Beginning of the Vear of Observation.

\begin{tabular}{|c|c|c|c|c|c|c|}
\hline * & \multicolumn{3}{|c|}{$\alpha \quad 1888.0$} & \multicolumn{2}{|c|}{$\delta 1888.0$} & Authority \\
\hline 1 & $5^{h}$ & & 34.48 & $+19^{\circ} 5^{\prime}$ & $15 " 4$ & ro ${ }^{\mathrm{m}}$. C p. with $\mathrm{W}_{2} 5^{\mathrm{h}} \mathrm{1} 68$ \\
\hline 2 & 5 & 8 & 33.77 & +1955 & 42.1 & $W_{2} 5^{h} \cdot 168$ \\
\hline 3 & 5 & 14 & 5 & +1950 & & DM. + I $9: 901$ \\
\hline 4 & 5 & & 19.63 & +1942 & 0.3 & $1 / 2\left(\right.$ Gl. I $\left.302+W_{2} 5 \cdot 345\right)$ \\
\hline 5 & 5 & 19 & $5^{2}$ & $+194 \mathrm{I}$ & & DM. +19.926 \\
\hline 6 & 5 & 23 & 9 & $+194 I$ & & DM. + $19: 937$ \\
\hline 7 & 5 & & 3.44 & +1932 & 57.8 & Rui. $145^{2}$ \\
\hline 8 & 7 & & 34 & +1235 & & DM. $+122^{\circ} \times 54^{6}$ \\
\hline 9 & 7 & 22 & 33.57 & +1222 & 8.7 & $\mathrm{~W}_{1} 7^{\mathrm{h} .622}$ \\
\hline 10 & 7 & 32 & 57.19 & +111 & 31.9 & $W_{1} 7: 955$ \\
\hline 11 & 7 & $5^{8}$ & 5.42 & +715 & $4 \cdot 5$ & Cp. with BB.VI $+7^{\circ} 1903$ \\
\hline 12 & 8 & 5 & 4.63 & $+6 \cdot 8$ & 31.8 & Cp. with $W_{1} 8$ h \\
\hline 13 & 8 & 14 & 51.82 & +3 & 5.6 & Lal. 16341 \\
\hline
\end{tabular}

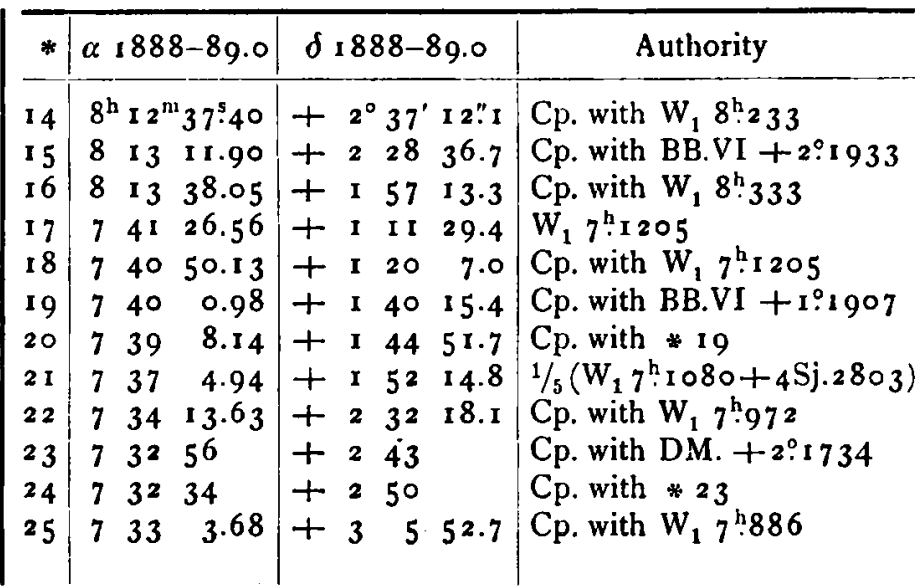

Micrometer-Comparisons.

\begin{tabular}{|c|c|c|c|c|c|c|c|c|c|c|}
\hline & $\Delta \alpha$ & & $\Delta \delta$ & Cp. & & & $1 \alpha$ & & $1 \delta$ & Cp. \\
\hline$* 1-W_{2} 5^{h} 168$ & $-3^{m} 3^{m} \cdot 9^{2}$ & +2 & 2' $33^{\prime \prime} 6$ & 6.3 & $* 19-\mathrm{BB} . \mathrm{VI}+1 \% 1907$ & 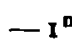 & $53^{3} \cdot 94$ & - & $0^{\prime} 38^{\prime \prime} .2$ & 10 \\
\hline * I I - BB.VI + $7^{\circ}$ 1 903 & +o 51.47 & + & $9 \quad 58.8$ & 6.3 & $* 20-* 19$ & -0 & 52.84 & + & $4 \quad 36.3$ & \\
\hline$* 12-W_{1} 8^{\mathrm{h}}: 8$ & $+\mathrm{I} 29.88$ & 一 & $6 \quad 57.2$ & 6.3 & $* 22-W_{1} 7^{h} \cdot 97^{2}$ & +o & 56.32 & + & 555.3 & \\
\hline$* 14-W_{1} 8^{\mathrm{h}} 233$ & +16.83 & - & $3 \quad 12.7$ & 8.3 & *23-DM. $+2^{\circ} 1734$ & -1 & 34.06 & + & 10.3 & \\
\hline$* 15-\mathrm{BB} . \mathrm{VI}+2 \% 1933$ & -0 3.97 & +4 & $4 \quad 54.7$ & 10.4 & $* 24-* 23$ & -0 & 21.48 & + & 640.8 & \\
\hline $\begin{array}{l}* 16-W_{1} 8^{\mathrm{h}} 333 \\
* 18-W_{1} 7^{\mathrm{h}} \times 205\end{array}$ & $\begin{array}{ll}-1 & 22.44 \\
-0 & 36.43\end{array}$ & $\begin{array}{l}+12 \\
+8\end{array}$ & $\begin{array}{ll}2 & 40.9 \\
8 & 37.6\end{array}$ & $\begin{array}{c}10.3 \\
6.3\end{array}$ & *25 $-W_{1} 7^{h} .886$ & +2 & 22.97 & - & 057.9 & \\
\hline
\end{tabular}

In determining the place of the comparison star of Nov. 4, I compared it with $\dot{W}_{1} 7^{\mathrm{h}} \mathrm{i} 633$ as well as with BB.VI $+7^{\circ} 1903$. The place of the star from comparison with these two differed by $10 "$ in the declination. To find which of the comparison stars was in error I compared BB.VI $+7^{\circ} .1903$ with BB.VI $+7^{\circ} .1898$ and found that the error was in the Weisse star. The following are my measures of the apparent $\Delta \delta$ on 1889 April 18-24: BB.VI + $7^{\circ} 1903-$ $\mathrm{W}_{1} 7^{\mathrm{h}} 16_{33}=-2 \mathrm{I}^{\prime} \mathrm{I}_{7.7}$ ( $\mathrm{r}_{2}$ obs.) using the intermediate comparison star. This difference from the brought up places of the two stars $=2 \mathrm{I}^{\prime} 27^{\prime \prime} 7$. On April $25 \mathrm{my}$ measures of the apparent $\Delta \delta$ : BB.VI $+7^{\circ} \mathrm{r} 903-\mathrm{BB}$.VI $+7^{\circ} \mathrm{1} 898=$ $-5^{\prime}$ o."6 (3 obs.). The difference from the brought up places $=-4$ ' 59 ". I. So it is evident that the Decl. of $\mathrm{W}_{1} 7^{\mathrm{h}} 16_{33}$ is to be corrected by $\left.-10^{\prime \prime} . *\right)$

M: Hamilton 1889 May 31 .

E. E. Barnard.

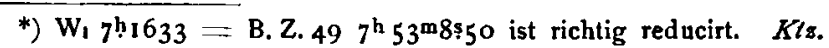

\title{
Ueber die Erscheinungen am Cometen 1889 ... (Brooks Juli 6).
}

\author{
Von Prof. Dr. E. Weiss.
}

\section{[Mit einer Tafel.]*)}

Als in der Nacht vom 4. auf 5. August die Depesche der Centralstelle über die Theilung des Brooks'schen Coineten einlief, war der Himmel zwar verschleiert, doch immerhin in einem so geringen Maasse, dass eine Wahrnehmung dieses interessanten Phänomens nicht als ganz noffnungslos erschien. Wir richteten daher den grossen Refractor auf den Cometen und bemerkten sofort, dass ihm zwei Nebelmassen in der Entfernung von $15^{\mathrm{s}}$ und $24^{\mathrm{s}}$ etwas nördlich folgten. Der Kern erschien für den ersten flüchtigen Anblick bloss sehr in die Länge gezogen und stark granulirt. Bei aufmerksamerer Betrachtung erkannte man jedoch, dass auch er aus zwei getrennten, allerdings noch durch eine blasse Nebelmasse mit einander verbundenen Kernen bestehe, der Comet sich daher eigentlich in 4 Theile gespalten habe. Da nun in der Depesche des Lick Observatory angegeben war, er habe sich in 3 Theile getrennt, meldete ich nach Kiel, dass derselbe bereits vierfach sei; dem in Nr. 2914 der A. N. abgedruckten Ergän. zungstelegramme zufolge scheint indess die Trennung in 4 Theile schon am 1 . August bestanden zu haben.

Für das Feststellen des Zeitpunktes der Trennung dürte es nicht ohne Interesse sein zu bemerken, dass Herr Spitaler bei seinen Beobachtungen des Cometen am 30. und 31. Juli an demselben, ebenfalls am grossen Refractor, und

*) Die Tafel wird den Abonnenten nachgeliefert. $K t z$. 